\title{
The Role of Progress Factors Explaining Inefficiencies in Transition Countries
}

\author{
Ebru Guven Solakoglu • M. Nihat Solakoglu • \\ Nazmi Demir
}

Published online: 8 December 2012

(C) Springer-Verlag Wien 2012

\begin{abstract}
This paper examines whether progress in transition has a significant effect on the economic efficiency for 24 transition countries from 1990 to 2006. It uses nine progress factors to analyze the role of the progress factors to explain inefficiencies. It also questions the effect of the transition countries that recently joined the European Union on efficiency. The results suggest that the average efficiency scores for EU-N10 are much higher than the average efficiency scores for SEE/CIS. The scores increase over time for both groups of transition countries. Reforms also contribute to efficiency in general.
\end{abstract}

Keywords Transition economies - Stochastic frontier analysis · Progress factors

JEL Classification $\quad \mathrm{P} 27 \cdot \mathrm{C} 1$

\section{Introduction}

In the first half of the 1990s socioeconomic conditions and the transformation as well as the starting points restrained transition countries economic structures in the transition period. Transition countries renovating themselves from command economies towards market driven economies experienced an initial large decline in production, a condition

E. G. Solakoglu ( $\bowtie)$

Banking and Finance, LC 109, Bilkent University, Bilkent, Ankara, Turkey

e-mail: egsolakoglu@bilkent.edu.tr

M. N. Solakoglu

Banking and Finance, LC 113, Bilkent University, Bilkent, Ankara, Turkey

e-mail: nsolakoglu@bilkent.edu.tr

N. Demir

Banking and Finance, LC 108, Bilkent University, Bilkent, Ankara, Turkey

e-mail: nazmi@bilkent.edu.tr 
that all transition economies shared. ${ }^{1}$ Transition to a market economy required significant restructuring processes, reallocation of labor between sectors. After the mid1990s market-oriented policy reforms have played a significant role in promoting subsequent economic growth (Boeri and Terrel 2002; Kornai 2006). However, output depicted a rapid growth mostly in the Baltic countries, while the growth rate was slower in others. Farm restructuring and the liberalization of marketing institutions proceeded more gradually in most of the Common Independent States (CIS) compared with the Central and Southeastern Europe and the Baltic (CSB) countries.

Attempts to explain the performance of transition countries focused on and supported the role of initial conditions and policies (De Melo et al. 1997; Falcetti et al. 2002). Recent work has been more reluctant to explain the progress focusing on the initial conditions. The focus shifted from calendar time to "transition time" and on the endogeneity of reforms, the role of government, etc. (Firdmuc 2003; Lysenko 2002; Falcetti et al. 2005).

Pertaining the performance of the transition countries can be elucidated in how effective policies have been implemented in two respects: how old enterprises have been disciplined and how the new ones have been encouraged. Estonia, Hungary, Poland for example succeeded in both and performed relatively better. Bulgaria, the Kyrgyz Republic, Moldova, Romania, Russia, and Ukraine succeeded in the latter, yet failed in the first. Belarus, Turkmenistan and Uzbekistan are countries to the case in point that failed in both (World Bank 2002).

In the transition period various and ranging factors have been acknowledged to be main contributors to the success of transition economies. Establishing and maintaining discipline, implementing reforms in labor and financial markets and social protection system promoting the development and maintenance of human capital, as well as generating an investment environment for the entry of SMEs, particularly, are examples of effective policies in the transition process. Along with the effective policies, institutional change is renowned to be an integral part, especially if the political systems affect the incentives of politicians to follow certain reforms.

In this context, countries that went through the accession process and prepared to be members of the European Union (EU) were better candidates, if not for all, for most, when compared to the rest of the transition countries, in discipline, for imposing hard budget constraints and trade liberalization and for enforcing competition with necessary monitoring. The adoption of laws for property rights that support the investment environment for both domestic and foreign investors is another significant advance in reform for the accession countries. However, whether such progress in transition enables a country to achieve more economic efficiency is an issue that we aim to discuss in this study.

This study measures (in)efficiencies of 24 transition countries, eight of which are the new members of the EU, by incorporating the effects of structural and institutional progress. This analysis will not only help us to see the performance of transition countries, but also analyze the efficiency differences across transition

\footnotetext{
1 Output decline was highest in Georgia (about $80 \%$ decline) and very high in Armenia and Moldova, whereas Poland had the mildest decline of about $6 \%$. The CEB/SEE average was about $23 \%$, and the CIS average was about $50 \%$.
} 
countries and specify which reforms contribute to (in)efficiencies the most. We will also discover whether the accession process to the EU, finalizing in membership, has any significant effect on the implementation of reforms and (in)efficiencies.

The paper proceeds as follows. "Data and Empirical Application" describes the data and the empirical application to measure efficiency scores along with inefficiency factors. "Empirical Results" provides the results and discusses the role of inefficiency factors on efficiency, in detail, accounting for the transition progress time. "Final Remarks" concludes the paper.

\section{Data and Empirical Application}

The empirical analysis uses data on 24 countries, grouped under EU-N10 and SEE/ CIS, from 1990 to 2006. EU-N10 includes the countries that joined the EU as of May 2004. SEE/CIS stands for other transition countries in Southeastern Europe (SEE) and Common Independent States (CIS). The list of countries is presented in Table 1 below. We analyze the countries in two groups to compare the technical change, efficiency change and productivity growth. Table 1 shows that the average annual growth rates of real GDP is much higher for CEE countries compared to the SEE/CIS countries for the whole sample. However, two groups have approximately equal average annual growth rates of real GDP after 1995, showing that economic growth is promoted by market-oriented policy reforms, which started to show its effect after 1995 for most of the transition countries.

We obtained the GDP figures in constant 2000 US dollars from the World Development Indicators (WDI) and used it as the output data. Labor statistics and capital stock figures are also obtained from the same source. Following Easterly and Levine (2001), we used a perpetual inventory method to compute capital stocks. Capital is represented as $\mathrm{K}(\mathrm{t})=\mathrm{k}^{*} \mathrm{GDP}(\mathrm{t})$, where $\mathrm{k}$, the capital-output ratio, was computed as $\mathrm{k}=\mathrm{i} /(\mathrm{g}+\mathrm{d})$, assuming that countries are at their steady state initially. In this equation, i represents the ratio of investment [gross fixed capital formation in constant 2000 US dollars, $\mathrm{I}(\mathrm{t})$ ] to output, $\mathrm{g}$ is the average growth rate of real output, and $d$ is the depreciation rate, which is assumed to equal 0.07. After calculating the initial capital stock, we calculate capital for the following years with the equation $\mathrm{K}(\mathrm{t}+1)=(1-\mathrm{d}) \mathrm{K}(\mathrm{t})+\mathrm{I}(\mathrm{t})$.

In addition, we use transition progress data published by the European Bank for Reconstruction and Development (EBRD) to analyze the effect of progress in transition on the performance of the transition countries. EBRD offers four categories that include nine factors to indicate structural and institutional progress; enterprises including the index of small-scale privatization, large-scale privatization, and enterprise reform; markets and trade, including the index of price liberalization, foreign exchange system, and trade liberalization and competition policy; financial sector, including the index of banking sector reform and the reform of non-bank financial institutions; and the index of infrastructure reform. ${ }^{2}$

\footnotetext{
2 Cyprus and Malta did not provide transition progress data and, hence, were excluded from the analysis. Serbia and Turkmenistan were also excluded from the analysis due to their scattered data. Therefore, we continued our analysis with 24 countries, although we originally obtained data on 28 countries.
} 
Table 1 List of transition countries and their real GDP growth rates

\begin{tabular}{|c|c|c|c|c|c|}
\hline New EU-10 & $\begin{array}{l}\text { Real GDP } \\
\text { growth }(\%) \\
1990-2006\end{array}$ & $\begin{array}{l}\text { Real GDP } \\
\text { growth }(\%) \\
1995-2006\end{array}$ & SEE/CIS & $\begin{array}{l}\text { Real GDP } \\
\text { growth }(\%) \\
1990-2006\end{array}$ & $\begin{array}{l}\text { Real GDP } \\
\text { growth (\%) } \\
1995-2006\end{array}$ \\
\hline Cyprus & 3.88 & 3.57 & Albania & 3.39 & 5.55 \\
\hline Czech Republic & 1.79 & 2.96 & Armenia & 3.14 & 9.11 \\
\hline Estonia & 3.05 & 7.35 & Azerbaijan & 3.77 & 12.56 \\
\hline Hungary & 2.16 & 4.15 & Belarus & 2.43 & 7.22 \\
\hline Latvia & 2.05 & 7.39 & Bulgaria & 1.05 & 2.66 \\
\hline Lithuania & 1.15 & 6.18 & Croatia & 1.11 & 4.17 \\
\hline Malta & 3.60 & 2.74 & Georgia & -1.71 & 6.89 \\
\hline Poland & 3.77 & 4.43 & Kazakhstan & 1.82 & 6.85 \\
\hline Slovak Republic & 2.30 & 4.52 & $\begin{array}{l}\text { Kyrgyz } \\
\text { Republic }\end{array}$ & -0.79 & 4.55 \\
\hline \multirow[t]{9}{*}{ Slovenia } & 2.61 & 4.04 & $\begin{array}{l}\text { Macedonia, } \\
\text { FYR }\end{array}$ & 0.14 & 2.30 \\
\hline & & & Moldova & -3.16 & 2.54 \\
\hline & & & Romania & 1.32 & 2.75 \\
\hline & & & $\begin{array}{l}\text { Russian } \\
\text { Federation }\end{array}$ & 0.09 & 4.21 \\
\hline & & & $\begin{array}{l}\text { Serbia and } \\
\text { Montenegro }\end{array}$ & 5.21 & 5.21 \\
\hline & & & Tajikistan & -1.88 & 5.10 \\
\hline & & & Turkmenistan & -2.04 & 4.82 \\
\hline & & & Ukraine & -1.93 & 3.32 \\
\hline & & & Uzbekistan & 2.10 & 4.88 \\
\hline $\begin{array}{l}\text { Average annual } \\
\text { growth rate of } \\
\text { real GDP }\end{array}$ & 2.64 & 4.73 & & 0.78 & 5.26 \\
\hline
\end{tabular}

To analyze the economic performance of transition countries, we consider the stochastic frontier specification of a production function that allows the error to be divided into an inefficiency component, which may represent random effects beyond the control of the economy. This decomposition of the error term, developed by Battese and Coelli (1992), allows for the simultaneous estimation of the production function and the inefficiency function. ${ }^{3}$ In this study, we utilize the translog specification, a flexible form of the production function:

$$
\begin{aligned}
\ln Y_{i t}= & \beta_{0}+\beta_{1} \ln X_{1 i t}+\beta_{2} \ln X_{2 i t}+\frac{1}{2} \beta_{3}\left(\ln X_{1 i t}\right)^{2}+\frac{1}{2} \beta_{4}\left(\ln X_{2 i t}\right)^{2}+\beta_{5} \ln X_{1 i t} \ln X_{2 i t} \\
& +\varepsilon_{i t}
\end{aligned}
$$

where i denotes the country; t denotes time; ln represents the natural logarithm; $Y_{\text {it }}$ is gross domestic product at constant 2000 US dollars at time $t$ and for country $\mathrm{i}$; $\mathrm{X}_{1}$

\footnotetext{
${ }^{3}$ For a review of the theory and application of stochastic frontier models, see Coelli et al. (2005) and Kumbhakar and Knox Lovell (2003).
} 
is capital stock; $\mathrm{X}_{2}$ represents the labor force measured by the number of total employees. The error term is defined as $\varepsilon_{\mathrm{i}}=\mathrm{V}_{\mathrm{i}}-\mathrm{U}_{\mathrm{i}}$, where $\mathrm{V}_{\mathrm{i}}$ is the noise component and is independently and identically distributed with a $\mathrm{N}\left(0, \sigma_{\mathrm{v}}^{2}\right)$. The non negative $U_{i}$ error term, with similar properties to the noise component, captures firm specific technical inefficiencies and is independently and identically distributed with $\mathrm{N}\left(\mathrm{Z}_{\mathrm{i}} \delta, \sigma_{\mathrm{u}}^{2}\right)$. The mean of firm-specific technical inefficiency $\left(\mathrm{U}_{\mathrm{i}}\right), \mu_{\mathrm{i}}$, following Battese and Coelli (1995), is defined as the following:

$$
\mu_{i}=\delta_{0}+\sum_{j=1}^{10} \delta_{j} Z_{i j}
$$

$\mathrm{Z}_{\mathrm{i}}$, also called background variables, are vector of other factors that influence production directly, which may represent inefficiency. We assign the level of structural and institutional reforms as $\mathrm{Z}$ variables. EBRD provides a long sample of indices to measure the level of reforms for transition countries. The neat part of these indices is that they are all collected by the same source and are comparable across countries, since the definition and interpretation of the indices are the same for all countries. ${ }^{4}$ The indices, as indicated earlier, cover four main areas of reforms: liberalization, stabilization, privatization, and structural reforms. An index score ranges from 1 to $4.33,1$ indicating no reform and 4.33 corresponding to a wellfunctioning market economy. ${ }^{5}$ We use these cardinal scores of reform indices individually as inefficiency variables. Therefore, $\mathrm{Z}_{1}$ and $\mathrm{Z}_{2}$ represent the index of small-and large-scale privatization, and $Z_{3}$ represents the enterprise reform. $Z_{4}$ is the index of price liberalization; $Z_{5}$ represents trade liberalization, mostly foreign exchange system (forex); $\mathrm{Z}_{6}$ is the progress in the competition policy; and $\mathrm{Z}_{7}$ and $\mathrm{Z}_{8}$ represent the progress in banking sector reform and non-bank financial institutions, respectively. Finally, $\mathrm{Z}_{9}$ represents the index of infrastructure reform. In addition, we added one more $\mathrm{Z}$ variable to capture the differences between EU-N10 and other transition countries, SEE/CIS, when calculating the efficiency scores. Thus, $\mathrm{Z}_{10}$ is a dummy variable and is one if the country is a new member of the EU, namely EU-N10, and zero otherwise.

\section{Empirical Results}

We estimate the parameters of the production frontier and predict individual technical efficiencies by the maximum likelihood method using FRONTIER 4.1 software. ${ }^{6}$ The high gamma value $\left(\gamma=\sigma_{\mathrm{v}}^{2} / \sigma^{2}\right)$, found to be 0.79 , states that much of the variation in the composite error term is due to the inefficiency component. In addition, the null hypothesis $\mathrm{H}_{\mathrm{o}}: \beta_{\mathrm{jk}}=0$ (i.e., the cross-product terms of inputs in

\footnotetext{
${ }^{4}$ Note that the EBRD indicators are criticized based on their subjectivity and their ordinal nature as well as its use of policy input and output measures (Falcetti et al. 2002, Campos and Horvath 2005). Yet, another study by Rusinova (2007) uses both Campos and Horvath's corrected data set and EBRD data set and does not find any change in the main results.

5 See the appendix in Table 4 for the classification system for transition indicators.

6 See Coelli (1996).
} 
Table 2 Maximum likelihood estimates of the stochastic frontier function and technical inefficiency model for economic production

\begin{tabular}{llrr}
\hline & Parameter & Coeff. est. & t-stat \\
\hline Stochastic frontier & & & \\
Constant & $\beta_{0}$ & 9.8814 & 3.51 \\
$\ln ($ capital) & $\beta_{1}$ & 0.3739 & 2.20 \\
$\ln ($ labor) & $\beta_{2}$ & 0.0054 & 0.02 \\
$\ln ^{2}$ (capital) & $\beta_{3}$ & 0.0566 & 30.60 \\
$\ln ^{2}$ (labor) & $\beta_{4}$ & 0.1275 & 4.54 \\
$\ln ($ capital*labor) & $\beta_{5}$ & -0.0680 & -5.69 \\
Technical inefficiencies & & & \\
Constant & $\delta_{0}$ & 1.0401 & 8.03 \\
Small-scale privatization & $\delta_{1}$ & 0.1359 & 2.30 \\
Large-scale privatization & $\delta_{2}$ & 0.2451 & 3.55 \\
Enterprise reform & $\delta_{3}$ & -0.1321 & -1.02 \\
Price liberalization & $\delta_{4}$ & -0.1274 & -2.65 \\
Forex and trade liberalization & $\delta_{5}$ & -0.0408 & -0.81 \\
Competition policy & $\delta_{6}$ & 0.3698 & 4.34 \\
Banking sector reform & $\delta_{7}$ & -0.1111 & -1.03 \\
Reform of non-bank financial institutions & $\delta_{8}$ & -0.2348 & -2.62 \\
Infrastructure reform & $\delta_{9}$ & -0.3777 & -4.00 \\
Dummy for EU-N10 & $\delta_{10}$ & -1.5383 & -3.38 \\
Variance parameters & & & \\
& $\sigma^{2}$ & 0.1303 & 8.28 \\
Ln(likelihood) & $\gamma$ & 0.7909 & 18.77 \\
\hline
\end{tabular}

the translog frontier regression are zero) is strongly rejected. This statistic is based on the likelihood ratio $\left(\lambda=-2\left\{\log \left[\mathrm{L}\left(\mathrm{H}_{0}\right)\right]-\log \left[\mathrm{L}\left(\mathrm{H}_{1}\right)\right]\right\}\right)$ that is equal to 774.1 (with -552.82 and -165.77 of the restricted Cobb-Douglas and translog models, respectively), suggesting that the Cobb-Douglas specification is not adequate for our data. The null hypothesis $\mathrm{H}_{\mathrm{o}}: \delta_{\mathrm{j}}=0$ that specifies the absence of inefficiency factors (all inefficiency coefficients but the intercept are zero) is also strongly rejected, based on the likelihood ratio of 230.7 (i.e., the values for the restricted and the unrestricted translog models are -165.77 and -50.40 , respectively). The elasticities of inputs in the frontier, evaluated at the sample means, are 0.57 for fixed capital and 0.45 for labour, indicating that constant returns to scale are the dominating feature of the sample. ${ }^{7}$ The results are presented in Table 2.

The estimated parameters of inefficiency show a number of interesting results, including that some reform level variables are significant in their effects. Some

\footnotetext{
${ }^{7}$ Labor at the linear level is insignificant, suggesting possible over employment for the sample. Wage adjustments and quantity of labor moved in different directions when CEE and SEE/CIS were compared. See Boeri and Terrel (2002) for a discussion of labor market adjustments in transition countries.
} 


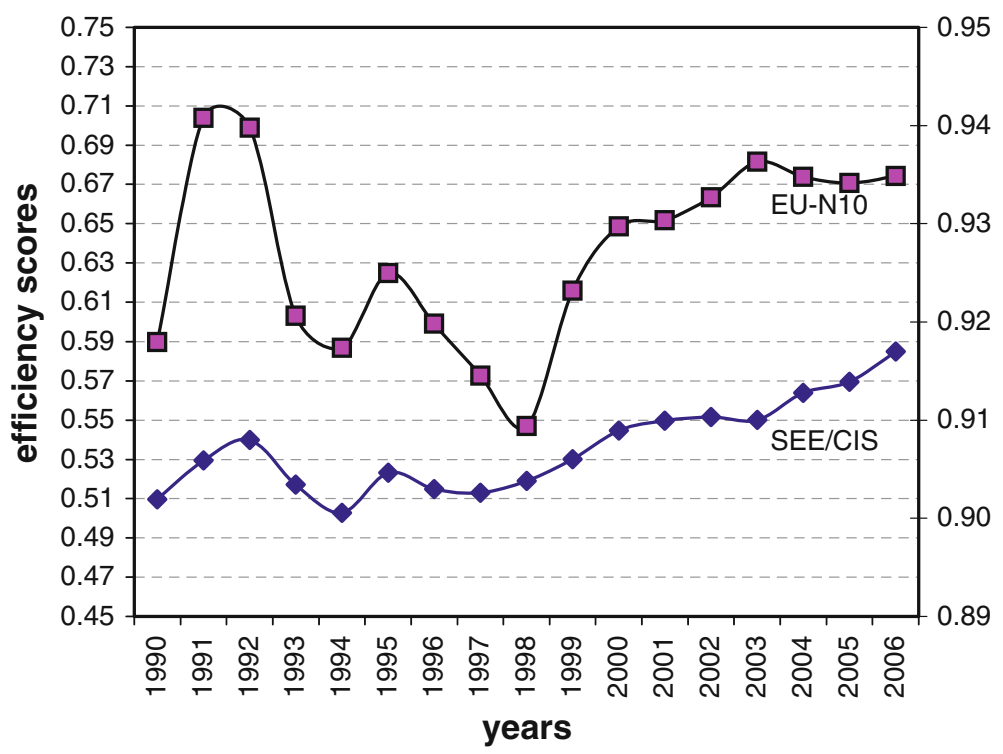

Fig. 1 Efficiency scores for EU-N10 and SEE/CIS

reforms of liberalization and stabilization suggest negative effects on efficiency (hence, positive estimates) and some show positive effects on efficiency (hence, negative estimates). Small-scale privatization and large-scale privatization, as well as competition policy appear to be significant and to affect the efficiency negatively. On the other hand, price liberalization, reforms on non-bank financial institutions, and infrastructure affect the economic efficiency positively. Enterprise reform, foreign exchange and trade liberalization, and banking sector reform do not have any affect on the economic efficiency.

The estimated parameter of the dummy variable for EU-N10 countries as an inefficiency factor is significant and negative, suggesting that being a new member of the EU has a significant positive effect on economic efficiency. Calculated inefficiency scores show that efficiency scores are significantly low in the CIS, on average, but this does not necessarily suggest that the growth rate of efficiency is lower in these countries. Figure 1 indicates the efficiency differences between EU-N10 and other transition countries.

The left side corresponds to the average efficiency scores for SEE/CIS from 1990 to 2006. For EU-N10, the average efficiency scores are represented on the right vertical axis. As seen from the figure, the average efficiency scores for EU-N10 are much higher than for SEE/CIS. However, they behave in the same direction. In other words, efficiency scores increase over time for both samples, except for a declining trend for EU-N10 from 1992 to $1998 .^{8}$

\footnotetext{
${ }^{8}$ If we include the former members of the European Union, EU-15, in our frontier analysis, so that EU-15 describes the frontier, then the average efficiency scores for EU-N10 and SEE/CIS are about 0.71 and 0.63 , respectively.
} 
Eff for Z1

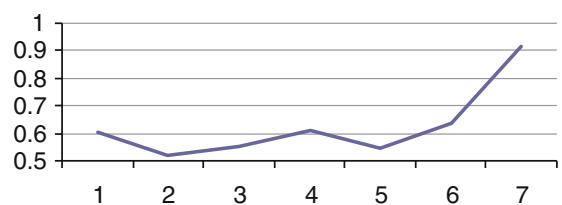

Eff for Z3

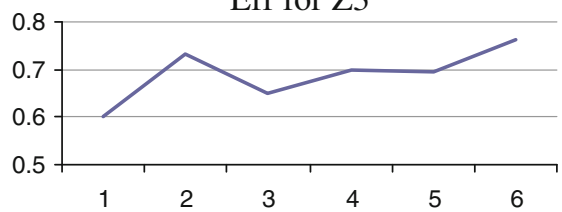

Eff for Z5

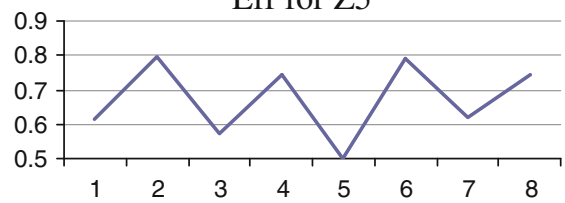

Eff for Z7

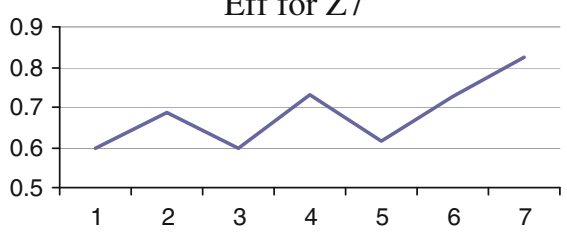

Eff for Z9

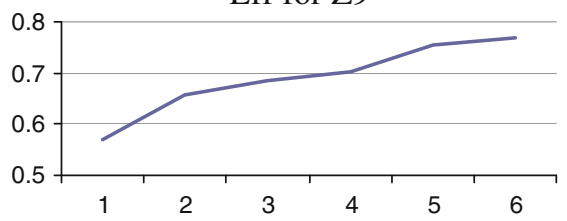

Eff for Z2

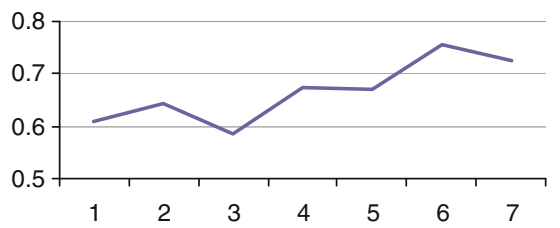

Eff for Z4

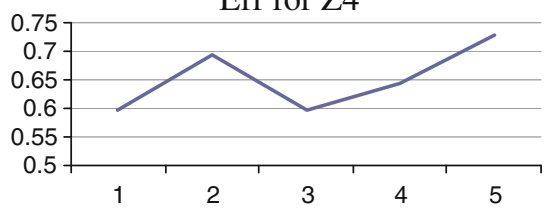

Eff for Z6

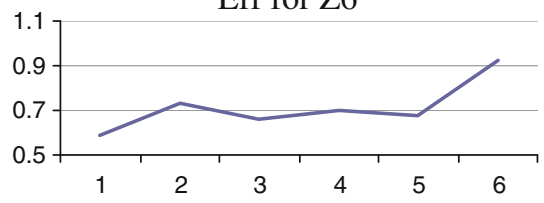

Eff for Z8

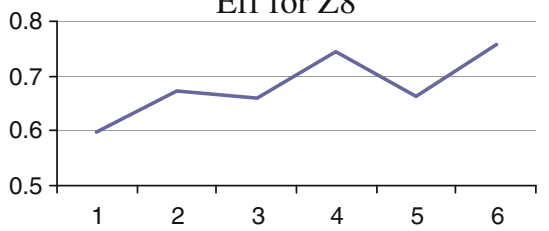

Fig. 2 The behavior of the efficiency scores with the progress factors

\section{Inefficiency Factors}

The first phase of transition started with privatization and liberalization. Liberalization reforms required ceasing intervention in economic activity; thus, market forces determined outcome. Privatization reforms required redistribution of the assets away from the state. All these reforms required governing and restructuring but were mostly generated by market incentives and, hence, were relatively straightforward and simple to implement. The transition countries have largely completed these reforms. 
The next phase in the transition, which began at different times across transition countries, required institutional design, fundamental changes in the behavior of the state and society, and an authority to control the change, progress, and effectiveness. Reforms such as in the financial sector $\left(Z_{7}, Z_{8}\right)$, in competition policy $\left(Z_{6}\right)$, and in the development of a market-oriented infrastructure $\left(Z_{9}\right)$ showed modest progress, especially for CIS (other transition) countries. All these reforms studied in the next phase of transition were expected to be completed in a relatively short time span and required bigger challenges and a more constructive role for the state.

Figure 2 presents nine different graphs representing the relationship between efficiency scores and individual reform $(Z)$ scores. On the horizontal axis, we use $\mathrm{Z}$ categories from the lowest to the highest values. On the vertical axis, we report the average efficiency score that corresponds to each $\mathrm{Z}$ categories. Hence, in a way, we can observe whether efficiency improves, as progress factors improve.

From the figures, we see a positive relationship between efficiency scores and individual reform $(Z)$ scores, suggesting that as reforms are implemented and progressed, the efficiency increases. This result does not hold for one factor, however: foreign exchange and trade liberalization $\left(\mathrm{Z}_{5}\right)$. This factor does not significantly affect the efficiency, according to the figures.

In order to understand the role of the reform indicators individually and through transition time, as well as the effect of negotiating towards being a member of the EU, we repeated our analysis of production efficiency with ten different translog production functions. First, we included the EU-N10 dummy variable as the only inefficiency factor in the function. We found that being an EU-N10 country increases efficiency significantly. Then, in line with the transition progress steps, we continued our analysis by adding one factor at a time, first with privatization reforms, then with liberalization and financial reforms, and finally with infrastructure reform. ${ }^{9}$ The addition of each factor provided the same sign with significance, generally, and each step supported the addition of the new factor to the efficiency model, as it captured a variance in the efficiency, seen by the test statistics, $\lambda$. Table 3 provides a summary of our results.

Based on the likelihood ratio statistics, the restricted model imposing no inefficiency effects $(\lambda=165.77)$ is rejected, favoring all unrestricted models in Table 3. In addition, comparing the models with the previous model, as the previous model is the restricted one, the statistics show that all models except model 3 add significance to the previous model. In other words, the absence of the new inefficiency factor is strongly rejected with the next model, excluding the third.

The results suggest that small-and large-scale privatization do not affect efficiency significantly in the first phase of transition and decrease efficiency (have significant positive effects on inefficiency) in the following phase, regardless of the effect of other reforms. Governance and enterprise restructuring reform, on the other hand, increases efficiency significantly in the first phase of transition period, but it loses its significance on efficiency with concomitant improvement in financial institutions (banking reform and interest rate liberalization and progress in securities

\footnotetext{
9 We realize that all the transition countries follow the same transition path in general, but not strictly: not necessarily in a strict order, as in the models we propose.
} 
Table 3 Summary statistics for the analysis of $\mathrm{Z}$

\begin{tabular}{ccccccccccccc}
\hline Model & $\mathrm{Z}_{1}$ & $\mathrm{Z}_{2}$ & $\mathrm{Z}_{3}$ & $\mathrm{Z}_{4}$ & $\mathrm{Z}_{5}$ & $\mathrm{Z}_{6}$ & $\mathrm{Z}_{7}$ & $\mathrm{Z}_{8}$ & $\mathrm{Z}_{9}$ & $\mathrm{Z}_{10}$ & $\log \left[\mathrm{L}\left(\mathrm{H}_{1}\right)\right]$ & $\lambda^{\mathrm{b}}$ \\
\hline 1 & & & & & & & & & & $-/ \mathrm{S}$ & -95.94 & \\
2 & $-/ \mathrm{S}$ & & & & & & & & & $-/ \mathrm{S}$ & -93.29 & 5.3 \\
3 & $+/$. & $-/$. & & & & & & & & $-/ \mathrm{S}$ & -93.08 & 0.42 \\
4 & $+/$ & $+/$. & $-/ \mathrm{S}$ & & & & & & & $-/ \mathrm{S}$ & -86.05 & 14.06 \\
5 & $+/$ & $+/$. & $-/ \mathrm{S}$ & $-/ \mathrm{S}$ & & & & & & $-/ \mathrm{S}$ & -82.76 & 6.58 \\
6 & $+/ \mathrm{S}$ & $+/ \mathrm{S}$ & $-/ \mathrm{S}$ & $-/$. & $-/ \mathrm{S}$ & & & & & $+/ \mathrm{S}$ & -79.52 & 6.48 \\
7 & $+/ \mathrm{S}$ & $+/$. & $-/ \mathrm{S}$ & $-/$. & $-/ \mathrm{S}$ & $+/ \mathrm{S}$ & & & & $-/ \mathrm{S}$ & -76.33 & 6.38 \\
8 & $+/ \mathrm{S}$ & $+/ \mathrm{S}$ & $-/$. & $-/$. & $-/$. & $+/ \mathrm{S}$ & $-/ \mathrm{S}$ & & & $-/ \mathrm{S}$ & -67.15 & 18.36 \\
9 & $+/ \mathrm{S}$ & $+/ \mathrm{S}$ & $-/$. & $-/ \mathrm{S}$ & $-/$. & $+/ \mathrm{S}$ & $-/ \mathrm{S}$ & $-/ \mathrm{S}$ & & $-/ \mathrm{S}$ & -60.61 & 13.08 \\
10 & $+/ \mathrm{S}$ & $+/ \mathrm{S}$ & $-/$. & $-/ \mathrm{S}$ & $-/$. & $+/ \mathrm{S}$ & $-/$. & $-/ \mathrm{S}$ & $-/ \mathrm{S}$ & $-/ \mathrm{S}$ & -50.40 & 20.42 \\
\hline
\end{tabular}

$\lambda^{\mathrm{b}}$ stands for the likelihood ratio used to compare the translog model with the previous model $\mathrm{S}$ represents the high significance of incorporating inefficiency effects into the models

markets and non-bank financial institutions). Similar results can be seen for foreign exchange and trade liberalization.

Price liberalization, on the contrary, does not have a significant impact on efficiency, initially; later, however, with the reforms in financial institutions, it affects the efficiency positively. Competition policy has a significant negative effect on efficiency, regardless of the next reforms. Financial institutions and infrastructure reforms have significant positive effects on efficiency. ${ }^{10}$

\section{Final Remarks}

We analyzed whether reforms in transition countries achieve a higher level of economic efficiency and whether this level changes for the accession countries into the EU. In this context, we measured (in)efficiencies of 24 transition countries, eight of which are new members of the EU, by incorporating the effects of structural and institutional progress. This analysis helped us to compare the efficiency scores of transition countries across time, incorporating the reform elements. This way, we can have an idea about the performance of transition countries with specification of the reforms that contribute to (in)efficiencies the most.

We found that the average efficiency scores for EU-N10 are much higher than the average efficiency scores for SEE/CIS. The scores increase over time for both groups of transition countries. Reforms also contribute to efficiency in general.

When we analyze the factors of the progress as individual reforms, we find that small-and large-scale privatization do not have significant effects initially, but that

\footnotetext{
10 See Havrylyshyn et al. (1998), Stiglitz (1999), and Radulescu and Barlow (2002) for the relationship between the reform factors and growth. Havrylyshyn et al. (1998) show that liberalization affects performance more significantly than the quality of the institutional environment, which shows its impact in the later stages of transition. Stiglitz (1999) stresses the positive role of privatization along with governance on growth. Radulescu and Barlow (2002) find price liberalization to be the most important factor on growth, followed by restructuring and large-scale privatization.
} 
the factors of foreign exchange and trade liberalization, and later reforms affected the efficiency negatively. Large-scale privatization suffered from political struggles with insiders in state-owned companies for most of these countries and had to be kept on the policy agenda in the second phase of transition (EBRD 2002).

The effect of the competition policy reforms on the efficiency was found to be negative and significant for each model. These reforms are almost complete for most of the transition countries in the first phase of transition.

Another early reform for these countries was price liberalization, which was found to affect the efficiency positively with the introduction of non-bank financial institutions and infrastructure reforms. Two of the second phase reforms, reforms of non-bank financial institutions and infrastructure, were also found to affect the efficiency positively.

Interestingly, one reform of the first phase, enterprise reform-which completes to considerable improvement in corporate governance and new investment at the enterprise level - and two reforms of the second phase, foreign exchange and trade liberalization and banking sector reform, do not have any significant effect on efficiency.

\section{Appendix}

See Table 4

Table 4 Classification system for transition indicators

Large-scale privatisation

1 Little private ownership.

2 Comprehensive scheme almost ready for implementation; some sales completed.

3 More than $25 \%$ of large-scale enterprise assets in private hands or in the process of being privatised (with the process having reached a stage at which the state has effectively ceded its ownership rights), but possibly with major unresolved issues regarding corporate governance.

4 More than $50 \%$ of state-owned enterprise and farm assets in private ownership and significant progress with corporate governance of these enterprises.

$4+$ Standards and performance typical of advanced industrial economies: more than $75 \%$ of enterprise assets in private ownership with effective corporate governance.

Small-scale privatisation

1 Little progress.

2 Substantial share privatised.

3 Comprehensive programme almost ready for implementation.

4 Complete privatisation of small companies with tradable ownership rights.

$4+$ Standards and performance typical of advanced industrial economies: no state ownership of small enterprises; effective tradability of land.

Governance and enterprise restructuring

1 Soft budget constraints (lax credit and subsidy policies weakening financial discipline at the enterprise level); few other reforms to promote corporate governance.

2 Moderately tight credit and subsidy policy, but weak enforcement of bankruptcy legislation and little action taken to strengthen competition and corporate governance. 
Table 4 continued

3 Significant and sustained actions to harden budget constraints and to promote corporate governance effectively (for example, privatisation combined with tight credit and subsidy policies and/or enforcement of bankruptcy legislation).

4 Substantial improvement in corporate governance and significant new investment at the enterprise level, including minority holdings by financial investors.

4+ Standards and performance typical of advanced industrial economies: effective corporate control exercised through domestic financial institutions and markets, fostering market-driven restructuring.

Price liberalisation

1 Most prices formally controlled by the government.

2 Some lifting of price administration; state procurement at non-market prices for the majority of product categories.

3 Significant progress on price liberalisation, but state procurement at non-market prices remains substantial.

4 Comprehensive price liberalisation; state procurement at non-market prices largely phased out; only a small number of administered prices remain.

4+ Standards and performance typical of advanced industrial economies: complete price liberalisation with no price control outside housing, transport, and natural monopolies.

Trade and foreign exchange system

1 Widespread import and/or export controls or very limited legitimate access to foreign exchange.

2 Some liberalisation of import and/or export controls; almost full current account convertibility in principle, but with a foreign exchange regime that is not fully transparent (possibly with multiple exchange rates).

3 Removal of almost all quantitative and administrative import and export restrictions; almost full current account convertibility.

4 Removal of all quantitative and administrative import and export restrictions (apart from agriculture) and all significant export tariffs; insignificant direct involvement in exports and imports by ministries and state-owned trading companies; no major non-uniformity of customs duties for non-agricultural goods and services; full and current account convertibility.

4+ Standards and performance norms of advanced industrial economies: removal of most tariff barriers; membership in WTO.

Competition policy

1 No competition legislation and institutions.

2 Competition policy legislation and institutions set up; some reduction of entry restrictions or enforcement action on dominant firms.

3 Some enforcement actions to reduce abuse of market power and to promote a competitive environment, including break-ups of dominant conglomerates; substantial reduction of entry restrictions.

4 Significant enforcement actions to reduce abuse of market power and to promote a competitive environment.

4+ Standards and performance typical of advanced industrial economies: effective enforcement of competition policy; unrestricted entry to most markets.

Banking reform and interest rate liberalisation

1 Little progress beyond establishment of a two-tier system.

2 Significant liberalisation of interest rates and credit allocation; limited use of directed credit or interest rate ceilings.

3 Substantial progress in establishment of bank solvency and of a framework for prudential supervision and regulation; full interest rate liberalisation with little preferential access to cheap refinancing; significant lending to private enterprises and significant presence of private banks. 
Table 4 continued

4 Significant movement of banking laws and regulations towards BIS standards; well-functioning banking competition and effective prudential supervision; significant term lending to private enterprises; substantial financial deepening.

4+ Standards and performance norms of advanced industrial economies: full convergence of banking laws and regulations with BIS standards; provision of full set of competitive banking services.

Securities markets and non-bank financial institutions

1 Little progress.

2 Formation of securities exchanges, market-makers and brokers; some trading in government paper and/or securities; rudimentary legal and regulatory framework for the issuance and trading of securities.

3 Substantial issuance of securities by private enterprises; establishment of independent share registries, secure clearance and settlement procedures, and some protection of minority shareholders; emergence of non-bank financial institutions (for example, investment funds, private insurance and pension funds, leasing companies) and associated regulatory framework.

4 Securities laws and regulations approaching IOSCO standards; substantial market liquidity and capitalisation; well-functioning non-bank financial institutions and effective regulation.

4+ Standards and performance norms of advanced industrial economies: full convergence of securities laws and regulations with IOSCO standards; fully developed non-bank intermediation.

Infrastructure reform

The ratings are calculated as the average of five infrastructure reform indicators covering electric power, railways, roads, telecommunications, water, and waste water.

Source: http://www.ebrd.com/country/sector/econo/stats/timeth.htm

\section{References}

Battese GE, Coelli TJ (1992) Frontier production functions, technical efficiency and panel data: with application to paddy farmers in India. J Prod Anal 3:153-169

Battese GE, Coelli TJ (1995) A model for technical inefficiency effects in a stochastic frontier production function for panel data. Empir Econ 20:325-332

Boeri T, Terrel K (2002) Institutional determinants of labour reallocation in transition. J Econ Perspect 16:51-76

Campos N, Horvath R (2005) Objective measures of reform in transition (at last): determinants, reversals, and growth implications. Mimeo, Barheim

Coelli TJ (1996) A Guide to FRONTIER Version 4.1: A computer program for stochastic frontier production and cost function estimation, CEPA Working Paper No. 96/7, Armidale: Department of Econometrics, University of New England

Coelli TJ, Prasada Rao DS, O’Donnell CJ, Battese GE (2005) An introduction to efficiency and productivity analysis. 2nd ed. Springer, New York

De Melo M, Denizer C, Gelb A, Tenev S (1997) Circumstance and choice: the role of initial conditions and policies in transition economies, The World Bank-international finance corporation, Washington. Policy research paper 1866

Easterly W, Levine R (2001) It's not factor accumulation: stylized facts and growth models. World Bank Econ Rev 15(2):177-219

Falcetti E, Raiser M, Sanfey P (2002) Defying the odds: initial conditions reforms and growth in the first decade of transition. J Comp Econo 30:229-250

Falcetti E, Lysenko T, Sanfey P (2005). Reforms and growth in transition: re-examining the evidence, EBRD working papers, 90

Firdmuc J (2003) Economic reform, democracy and growth during post-communist transition. Eur J Polit Econ 19:583-604 
Havrylyshyn O, Izvorski I, van Rooden R (1998) Recovery and growth in transition economies 1990-97: a stylized regression analysis. working paper WP/98/141. IMF, Washington DC

Kornai J (2006) The great transformation of central eastern Europe: success and disappointment, presidential address at the international economic association World Congress, Marrakech, Morocco (Aug 2005). Econ Transit 14(2):207-244

Kumbhakar SC, Knox Lovell CA (2003) Stochastic frontier analysis. Cambridge University Press, Cambridge

Lysenko T (2002) Determinants of economic growth in transition economies, M. Phil Dissertation. Cambridge University, Cambridge

Radulescu R, Barlow D (2002) The relationship between policies and growth in transition countries. Econ Transit 10(3):719-745

Rusinova D (2007) Growth in transition: reexamining the roles of growth factor inputs and geography. Econ Syst 10(3):719-745

Stiglitz J (1999) Whither Reform? Ten years of the transition, paper presented at the World Bank annual conference on development economics. April, Washington DC

World Bank (2002) Transition. The first ten years. Analysis and lessons for eastern Europe and the Soviet Union. World Bank, Washington DC 